\title{
Effects of Social Support, Functional Status, and Depression on the Quality of Life of Stroke Patients: A Meta-Analysis
}

\author{
Anwar Wahyudi'), Didik Gunawan Tamtomo²), RB Soemanto3) \\ ${ }^{1)}$ Masters program in Public Health, Universitas Sebelas Maret \\ 2)Faculty of Medicine, Universitas Sebelas Maret \\ 3)Faculty of Social and Political Sciences, Universitas Sebelas Maret
}

\section{ABSTRACT}

Background: Stroke patients have physical, social, and psychological disorders. It inhibits their daily activities, thus affecting the quality of life. This study aimed to analyze the effect of social support, functional status, and depression on the quality of life of stroke patients.

Subjects and Method: This study was a meta-analysis study. The data were obtained from Clinical Key, DOAJ, PubMed, Science Direct, Proquest, Scopus, and Google Scholar. The keywords were "social support" AND "functional status" AND "depression" AND "quality of life "AND" stroke". The articles were published from January 1991 to September 2020. The articles studied were full-text-articles with a cross-sectional and cohort study design. The articles were collected using the PRISMA diagram and analyzed using the RevMan 5.3 program.

Results: This study obtained 12 articles consisted of 2,015 selected stroke patients. The result of the meta-analysis showed that social support had a significant positive effect on the quality of life of stroke patients $(b=$
$0.03 ; 95 \% \mathrm{CI}=0.02$ to $0.05 ; \mathrm{p}=0.0001$ ), functional status had a significant positive effect on the quality of life of stroke patients $(b=0.63 ; 95 \% \mathrm{CI}=0.52$ to $1.08 ; \mathrm{p}=0.0001)$, and depression had a significant negative effect on the quality of life of stroke patients $(b=-0.18 ; 95 \% C I=-0.26$ to $-0.10 ; p=0.0001)$. Conclusion: Social support and functional status improve the quality of life of stroke patients. Depression reduces the quality of life of stroke patients.

Keywords: social support, functional status, depression, quality of life, stroke

\section{Correspondence:}

Anwar Wahyudi. Masters Program in Public Health, Universitas Sebelas Maret, JL. Ir Sutami 36A, Surakarta 57126, Central Java. Email: $\quad$ arwanwahyudi851@gmail.com. Mobile: +62813106121049.

\section{Cite this as:}

Wahyudi A, Tamtomo DG, Soemanto RB (2020). Effects of Social Support, Functional Status, and Depression on the Quality of Life of Stroke Patients: A Meta-Analysis. J Health Promote Behav. 05(04): 284295. https://doi.org/10.26911/thejhpb.2020.05.04.06.

(i) (2) Journal of Health Promotion and Behavioris licensed under a Creative Commons cc)

\section{BACKGROUND}

Stroke is a major health problem which is increasing each year. Stroke is the second leading cause of death in the world after ischemic heart disease (Setiawan et al., 2018; Zhu, 2019). Global Burder of Disease (GBD) reported that there were more than 9.5 million new cases of ischemic stroke in 2016, more than 2.7 million deaths occurred due to ischemic strokes, and almost $60 \%$ occurred under 70 years of age (Patel et al., 2019). In 2017, there were 11.9 million incidents of stroke, a prevalence of 104.2 million, 6.2 million were fatal, and 132.1 million had disabilities due to stroke. The incidence of stroke, prevalence, mortality, and disability decreased from 1990 to 2017, but the number of people who had 
new strokes, died, and survived had doubled (Krishnamurthi et al., 2020).

Several factors determined the quality of life of stroke patients were comorbidity, family support, functional status, morale, age, duration of illness, and depression (Elmawla et al., 2019; Fan et al., 2020).

Stroke caused about a third of sufferers to have long-termphysical, cognitive, psychological, and social disorders (Pedersen et al., 2019). Pratiwi et al., (2019) found that cognitive disorder was a risk factor for depression in stroke patients.

Stroke caused various changes such asphysical, social, and psychological changes. Physical changes were characterized by disability on one side of the body and inability to walk and do daily activities (Pei et al., 2016). Social changes in stroke patients were caused by the inability to communicate characterized by difficulties in speaking and language. Psychological changes were characterized by depression, anxiety, fatigue, sleep disorder, difficulty adapting, and lack of motivation in treatment (Terrill et al., 2018). These conditions decreased quality of life in stroke patients (Canuto et al., 2016).

Stroke patients had a decrease in quality of life, especially in psychological aspects, spiritual well-being, and tend to have depression (Bender et al., 2016). Depression occurred due to stroke had a negative effect on the quality of life in stroke patients (Batool et al., 2017; Hammed and Ugboh, 2018). Functional status affected the quality of life of stroke

\section{Eligibility Criteria}

The eligibility criteria used PICO (population, intervention, comparison, outcome).

\begin{tabular}{llll}
\hline & \multicolumn{1}{c}{ Social support } & Functional status & \multicolumn{1}{c}{ Depression } \\
\hline P & Patients after stroke & Patients after stroke & Patients after stroke \\
I & Strong social support & Good functional status & Major depression \\
C & Weak social support & Poor functional status & Minor depression \\
O & Quality of life & Quality of life & Quality of life \\
\hline
\end{tabular}

patients. According to Chaleoykitti et al., (2020), low functional status greatly affected the quality of life of stroke patients. Social support is important for rehabilitation and reintegration into the community (Lima et al., 2019). In addition, stroke patients also need intensive health care to improve their quality of life (Pandit, 2020).

This study used a systematic review for studies relevant to the meta-analysis. This study aimed to analyze the effect of social support, functional status, and depression on the quality of life of stroke patients.

\section{Study Design}

This study was a meta-analysis study. The main observation in this study was to analyze the effect of social support, functional status, and depression on the quality of life of stroke patients.

\section{Data search strategy}

The data were searched from a systematic and comprehensive database of several indexes such as Clinical Key, DOAJ, PubMed, Science Direct, Proquest, Scopus, and Google Scholar. The keywords were "social support" AND "functional status" AND "depression" AND "quality of life" AND "stroke".

\section{Population and Sample}

The population of this study was poststroke patients, both ischemic and hemorrhagic. 
Wahyudi et al./ Social Support, Functional Status, Depression, and Quality of Life

\section{Inclusion Criteria}

The study subjects were stroke patients aged $\geq 18$ years, full-text articles published in English, articles with observational studies (cross-sectional and cohort study design). In addition, the statistical results reported were the results of multivariate analysis ( $\beta$-coefficient) and the quality of life assessments used a valid scale.

\section{Exclusion criteria}

Stroke patients aged $\leq 18$ years, articles with RCT study designs, quasi-experimental, case-control and protocol studies, nonEnglish articles, duplicated articles, nonmultivariate analysis ( $\beta$-coefficient), and quality of life assessments used an invalid scale.

\section{Study Variables}

The independent variables were social support, functional status, and depression. The dependent variable was quality of life.

\section{Operational Definition of Variables}

Stroke was a clinical syndrome caused by a focal and global brain disorder with symptoms lasting 24 hours or more. Stroke was diagnosed through physical and radiological check-up (MRI/CT scan).

Social support was support or assistance that came from family, relatives, friends, and organizations. Social support used a continuous scale with the categories of weak and strong social support.

Functional status was the ability to do self-care activities independently. Functional status was measured using a continuous scale with the categories of low and high functional status.

Depression was a mood disorder characterized by feelings of deep sadness and ignorance. Depression was measured using a continuous scale with the categories of minor and major depression.
Quality of life was an individual's perception of his/her life position in the context of culture and value systems where individuals lived. It was related to goals, expectations, and problems. The quality of life used the SF-36, QLI, EUROQoL-5D-3L, SSQoL, SIS 3.0, and SIS-16 scales.

\section{Statistical analysis}

The data were analyzed using the Review Manager (Rev-Men) 5.3 program to calculate the adjusted Odds Ratio (aOR/ $\beta$-coefficient) that were adjusted as a whole (Karlinda et al., 2019).

\section{Selection from study}

The total number of articles collected was 2,558 articles. After reviewing and evaluating each article from each related website, there were 12 articles with a total sample of 2,015 stroke patients consisting of 2 articles on social support (Choi-Kwon et al., 2016) and (Perry dan McLaren, 2004), 5 articles on functional status (Chaleoykitti et al., 2020), (Chen et al., 2015), (Gunaydin et al., 2011), (Gurcay et al., 2009), (Khalid et al., 2016), and 6 articles on depression (AdeyWakeling et al., 2016), (Minshall et al., 2020), (Chen et al., 2015), (Cumming et al., 2014), (Perry and McLaren, 2004b), (Wulsin et al., 2012).

\section{The characteristics of the study}

The number of the sample included in the inclusion criteria was 2,015 post-stroke patients. The articles came from UK, South Korea, Australia, China, USA, Thailand, Taiwan, Turkey, and Pakistan.

\section{Social support}

Table 1 shows that there were 2 articles of the study on the effect of social support on the quality of life of stroke patients using the cohort study design. 
Wahyudi et al./ Social Support, Functional Status, Depression, and Quality of Life

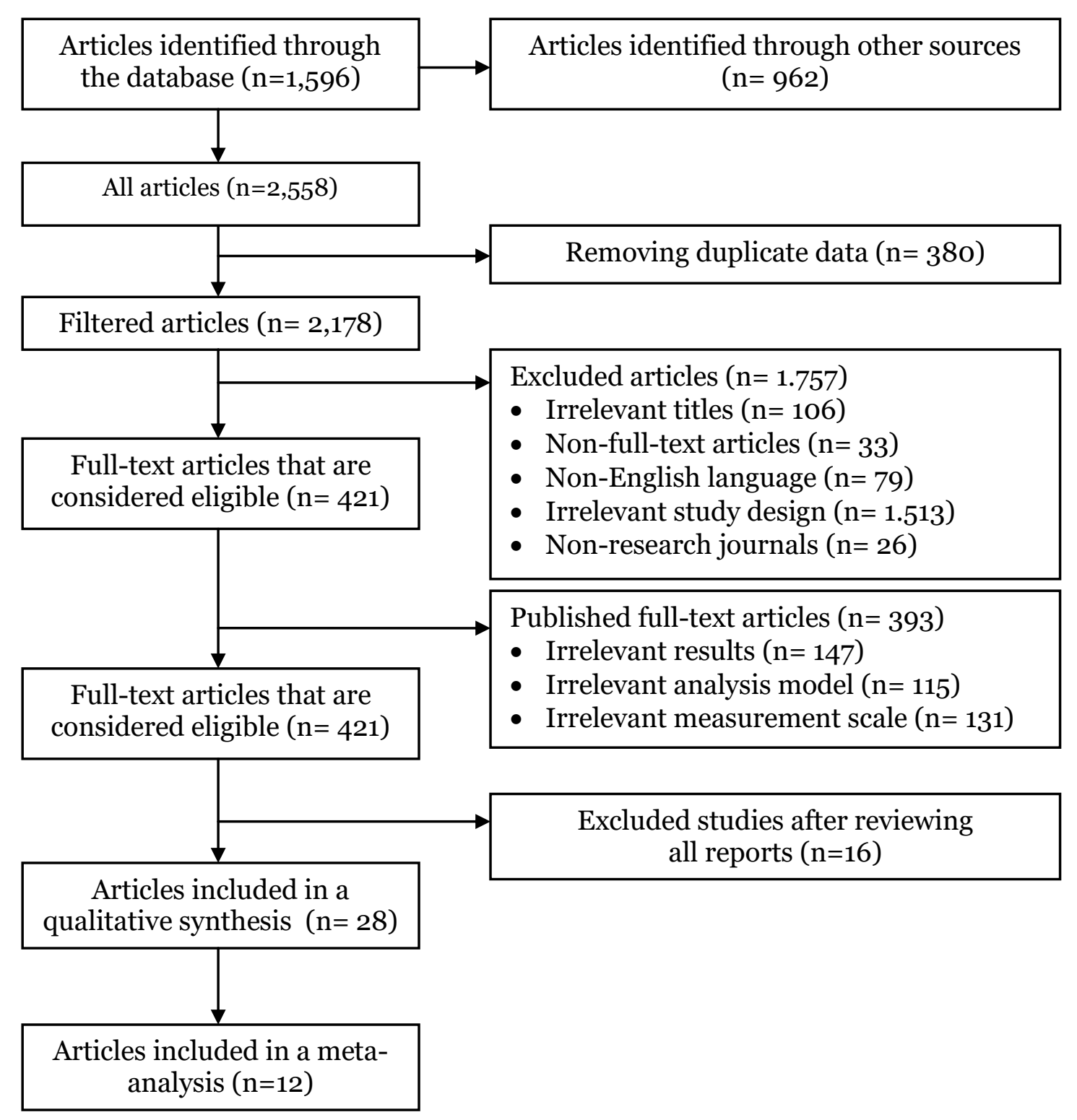

Figure 1. Diagram flow of the study selection

Table 1. The summary of source articles of the effect of social support on quality of life of stroke patients.

\begin{tabular}{|c|c|c|c|c|c|c|}
\hline $\begin{array}{c}\text { Author } \\
\text { (year) }\end{array}$ & Age & Country & $\begin{array}{c}\text { Study } \\
\text { design }\end{array}$ & $\begin{array}{c}\text { Total } \\
\text { sample }\end{array}$ & $\begin{array}{c}\text { Follow-up } \\
\text { duration }\end{array}$ & $\begin{array}{l}\text { Stroke, Social support, quality } \\
\text { of life }\end{array}$ \\
\hline $\begin{array}{l}\text { Choi- } \\
\text { Kwon et } \\
\text { al., } \\
(2016)\end{array}$ & $\begin{array}{l}\geq 60 \\
\text { years }\end{array}$ & $\begin{array}{l}\text { South } \\
\text { Korea }\end{array}$ & Cohort & 135 & $\begin{array}{l}12 \text { months } \\
\text { after stroke }\end{array}$ & $\begin{array}{l}\text { - Stroke: MRI. } \\
\text { - Social support: The ENRICHD } \\
\text { Social Support Instrument } \\
\text { - Quality of life: SF-36 }\end{array}$ \\
\hline $\begin{array}{l}\text { Perry dan } \\
\text { McLaren, } \\
\text { (2004) }\end{array}$ & $\begin{array}{l}\geq 65 \\
\text { years }\end{array}$ & UK & Cohort & 196 & $\begin{array}{l}6 \text { months } \\
\text { after stroke }\end{array}$ & $\begin{array}{l}\text { - Stroke: clinical check-up. } \\
\text { - Social support; The Medical Out- } \\
\text { comes Study Social Support Scale } \\
\text { - Quality of life: Quality of Life Index }\end{array}$ \\
\hline
\end{tabular}


Wahyudi et al./ Social Support, Functional Status, Depression, and Quality of Life

\section{a. Forest plot}

Figure 2 shows the forest plot of the effect of social support on the quality of life of stroke patients. The heterogeneity of the test results was $\left(\mathrm{p}=0.22 ; \mathrm{I}^{2}=34 \%\right)$, thus using the fixed-effect model (FEM). The result of the data analysis on the forest plot showed that social support had a significant positive effect on the quality of life of stroke patients $(\beta$-coefficient $=0.03 ; 95 \% \mathrm{CI}=$ 0.02 - 0.05; $\mathrm{p}=0.0001)$. Therefore, strong social support improved the quality of life of stroke patients.

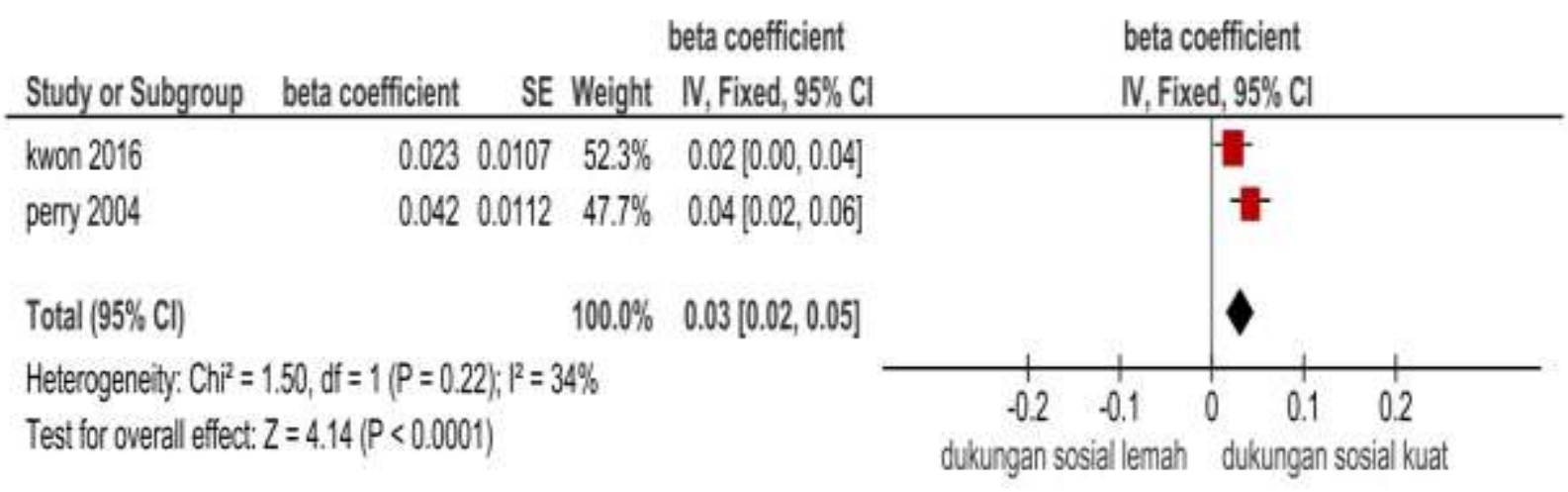

Figure 2. The forest plot of the meta-analysis of the effect of social support on the quality of life of stroke patients

\section{b. Funnel plot}

Figure 3 shows the funnel plot of the effect of social support on the quality of life of stroke patients. Since the articles combined

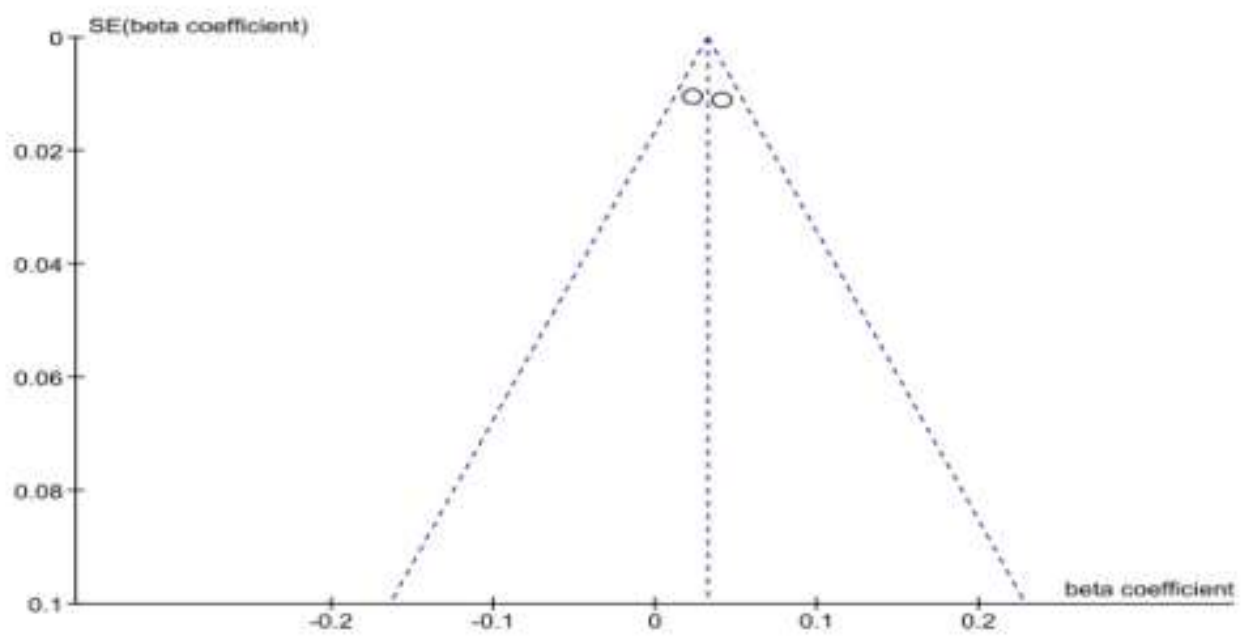

Figure 3 The funnel plot of the the meta-analysisof the effect of social support on the quality of life of stroke patients

\section{Functional status}

Table 2 shows that there were 5 articles regarding the effect of functional status on were only 2 articles, the publication bias on the effect of social support on quality of life could not be concluded. the quality of life of stroke patients using a cross-sectional study design. 
Wahyudi et al./ Social Support, Functional Status, Depression, and Quality of Life

Table 2. The summary of source articles of the effect of functional status on quality of life of stroke patients.

\begin{tabular}{|c|c|c|c|c|c|}
\hline $\begin{array}{l}\text { Author } \\
\text { (Year) }\end{array}$ & $\begin{array}{c}\text { Age } \\
\text { (Years) }\end{array}$ & Country & $\begin{array}{r}\text { Study } \\
\text { design }\end{array}$ & $\begin{array}{c}\text { Total } \\
\text { sample }\end{array}$ & $\begin{array}{l}\text { The criteria of stroke, functional } \\
\text { status, quality of life }\end{array}$ \\
\hline $\begin{array}{l}\text { Chaleoykitti et } \\
\text { al., (2020) }\end{array}$ & $\geq 60$ & Thailand & $\begin{array}{l}\text { Cross- } \\
\text { sectional }\end{array}$ & 113 & $\begin{array}{l}\text { - Stroke; brain imaging } \\
\text { - Status fungsional; BI (Barthel Index) } \\
\text { - Quality of life; WHOQOL-BREF }\end{array}$ \\
\hline $\begin{array}{l}\text { Chen et al., } \\
\text { (2015) }\end{array}$ & $30-80$ & Taiwan & $\begin{array}{l}\text { Cross- } \\
\text { sectional }\end{array}$ & 119 & $\begin{array}{l}\text { - Stroke; brain imaging } \\
\text { - Functional status; FIM } \\
\text { - Quality of life; SIS (stroke impact } \\
\text { scale) } 3.0\end{array}$ \\
\hline $\begin{array}{l}\text { Gunaydin et } \\
\text { al., (2011) }\end{array}$ & $\geq 18$ & Turkey & $\begin{array}{l}\text { Cross- } \\
\text { sectional }\end{array}$ & 80 & $\begin{array}{l}\text { - Stroke; MRI } \\
\text { - Functional status; FIM } \\
\text { - Quality of life; SSQOL }\end{array}$ \\
\hline $\begin{array}{l}\text { Gurcay et al., } \\
\text { (2009) }\end{array}$ & $33-80$ & Turkey & $\begin{array}{l}\text { Cross- } \\
\text { sectional }\end{array}$ & 67 & $\begin{array}{l}\text { - Stroke; CT scan/MRI } \\
\text { - Functional status; FIM } \\
\text { - Quality of life; SIS } 3.0\end{array}$ \\
\hline $\begin{array}{l}\text { Khalid et al., } \\
\text { (2016) }\end{array}$ & $\geq 18$ & Pakistan & $\begin{array}{l}\text { Cross- } \\
\text { sectional }\end{array}$ & 241 & $\begin{array}{l}\text { - Stroke; CT scan/MRI } \\
\text { - Functional status; FIM } \\
\text { - Quality of life; SSQOL }\end{array}$ \\
\hline
\end{tabular}

\section{a. Forest plot}

Figure 4 shows the forest plot of the effect of functional status on the quality of life of stroke patients. The heterogeneity of the test results was $\left(\mathrm{p}=0.00001 ; \mathrm{I}^{2}=93 \%\right)$, thus using a random-effect model (REM). The results of data analysis on the forest plot showed that functional status had a significant positive effect on the quality of life of stroke patients $(\beta$-coefficient $=0.63$; $95 \% \mathrm{CI}=0.36$ to $0.89 ; \mathrm{p}=0.0001)$. Therefore, good functional status improved the quality of life of stroke patients.

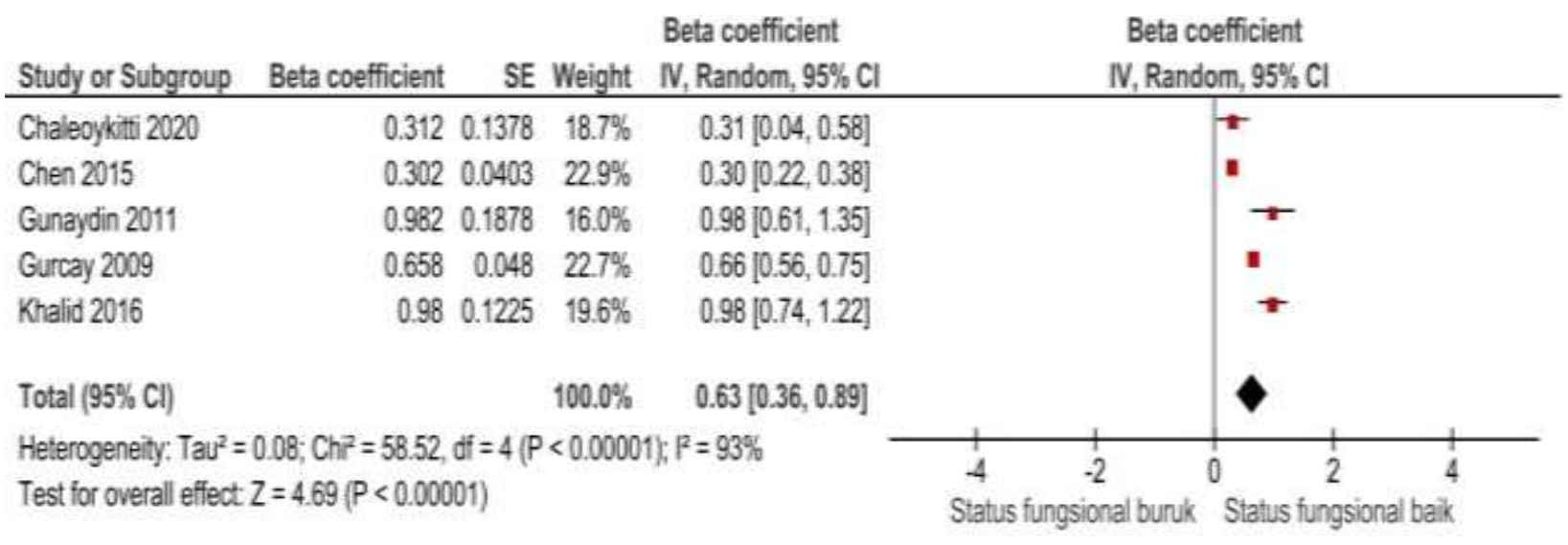

Figure 4. The forest plot of the effect of functional status on quality of life of stroke patients. 


\section{b. Funnel plot}

Figure 5 shows the funnel plot of the effect of functional status on the quality of life of stroke patients. The funnel plot figure showed that the distribution of the study was symmetrical. The distribution of plot points was balanced between the right and left sides of the centerline border. Therefore, there was no publication bias on the effect of functional status on the quality of life of stroke patients.

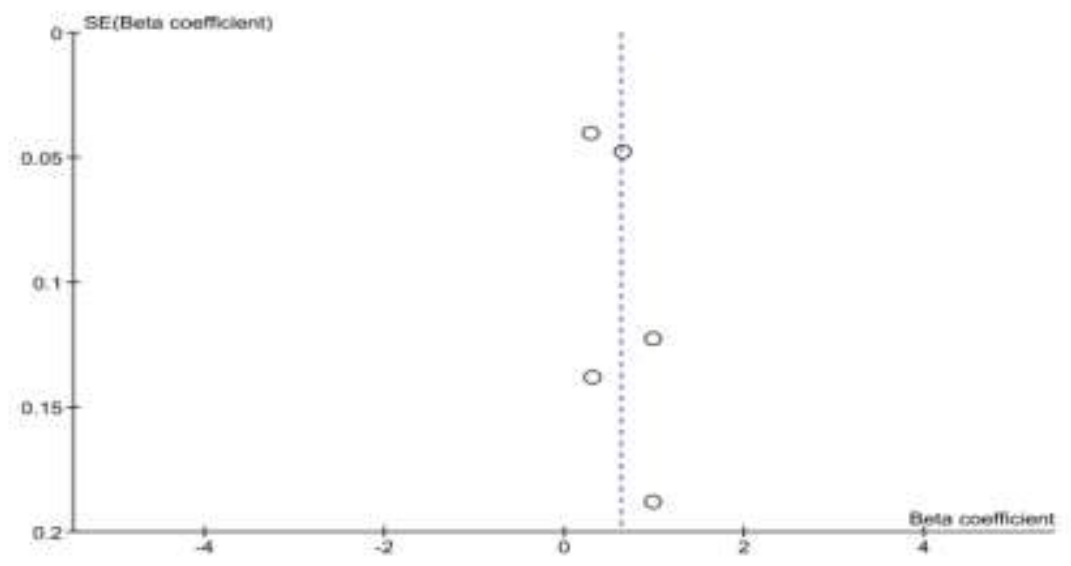

Figure 5. The funnel plot of the effect of functional status on quality of life of stroke patients

\section{Depression}

Table 3 shows that there were 6 articles regarding the effect of depression on the quality of life of stroke patients using a cohort study design.

Table 3. The summary of source articles of the effect of depression on quality of life of stroke patients.

\begin{tabular}{|c|c|c|c|c|c|c|}
\hline $\begin{array}{l}\text { Author } \\
\text { (Year) }\end{array}$ & Age & Country & $\begin{array}{c}\text { Study } \\
\text { design }\end{array}$ & $\begin{array}{c}\text { Total } \\
\text { Subjects }\end{array}$ & $\begin{array}{c}\text { Follow-up } \\
\text { duration }\end{array}$ & Stroke, Depression, quality of life \\
\hline $\begin{array}{l}\text { Adey- } \\
\text { Wakeling } \\
\text { et.al., } \\
\text { (2016) }\end{array}$ & $\begin{array}{l}34- \\
85 \\
\text { years }\end{array}$ & Australia & $\begin{array}{l}\text { Pros- } \\
\text { pective }\end{array}$ & 263 & $\begin{array}{l}12 \text { months } \\
\text { after stroke }\end{array}$ & $\begin{array}{l}\text { Stroke: radiology } \\
\text { Depression: Geriatric Depression Scale } \\
\text { Quality of life; EuroQoL -5D 3L }\end{array}$ \\
\hline $\begin{array}{l}\text { Minshall } \\
\text { et al., } \\
\text { (2020) }\end{array}$ & $\begin{array}{l}\geq 65 \\
\text { years }\end{array}$ & Australia & Cohort & 72 & $\begin{array}{l}33 \text { months } \\
\text { after stroke }\end{array}$ & $\begin{array}{l}\text { Stroke; clinical check-up } \\
\text { Depression; hospital anxiety \& depression } \\
\text { scale } \\
\text { Quality of life; AQOL-6D }\end{array}$ \\
\hline $\begin{array}{l}\text { Chen et } \\
\text { al., (2015) }\end{array}$ & $\begin{array}{l}40-80 \\
\text { years }\end{array}$ & China & Cohort & 218 & $\begin{array}{l}3 \text { months } \\
\text { after stroke }\end{array}$ & $\begin{array}{l}\text { Stroke; MRI } \\
\text { Depression; hospital depression rating scale } \\
\text { Quality of life; stroke specific quality of life }\end{array}$ \\
\hline $\begin{array}{l}\text { Cumming } \\
\text { et al., } \\
\text { (2014) }\end{array}$ & $\begin{array}{l}\geq 18 \\
\text { years }\end{array}$ & Australia & Cohort & 60 & $\begin{array}{l}3 \text { months } \\
\text { after stroke }\end{array}$ & $\begin{array}{l}\text { Stroke; medical record } \\
\text { Depression; hospital \& anxiety depression } \\
\text { scale } \\
\text { Quality of life; AQOL }\end{array}$ \\
\hline $\begin{array}{l}\text { Perry dan } \\
\text { McLaren } \\
(2004)\end{array}$ & $\begin{array}{l}\geq 65 \\
\text { years }\end{array}$ & UK & Cohort & 196 & $\begin{array}{l}6 \text { months } \\
\text { after stroke }\end{array}$ & $\begin{array}{l}\text { Stroke; clinical check-up } \\
\text { Depression; hospital anxiety \& depression } \\
\text { scale } \\
\text { Quality of life; Quality of Life Index }\end{array}$ \\
\hline $\begin{array}{l}\text { Wulsin et } \\
\text { al., (2012) }\end{array}$ & $\begin{array}{l}25-93 \\
\text { years }\end{array}$ & USA & Cohort & 322 & $\begin{array}{l}3 \text { months } \\
\text { after stroke }\end{array}$ & $\begin{array}{l}\text { Stroke; medical record } \\
\text { Depression; Center for Epidemiological } \\
\text { Studies Depression Scale } \\
\text { Quality of life; Stroke Specific Quality of } \\
\text { Life }\end{array}$ \\
\hline
\end{tabular}


Wahyudi et al./ Social Support, Functional Status, Depression, and Quality of Life

a. Forest plot

Figure 6 shows the forest plot of the effect of depression on the quality of life of stroke patients. The heterogeneity of the test results was $\left(\mathrm{p}=0.00001 ; \mathrm{I}^{2}=94 \%\right)$, thus using a random-effect model (REM). The results of the data analysis showed that depression had a significant negative effect on the quality of life of stroke patients $(\beta$ coefficient $=-0.18 ; 95 \% \mathrm{CI}=-0.26$ to -0.10 ; $\mathrm{p}=$ 0.00001). Therefore, major depression reduced the quality of life of stroke patients.

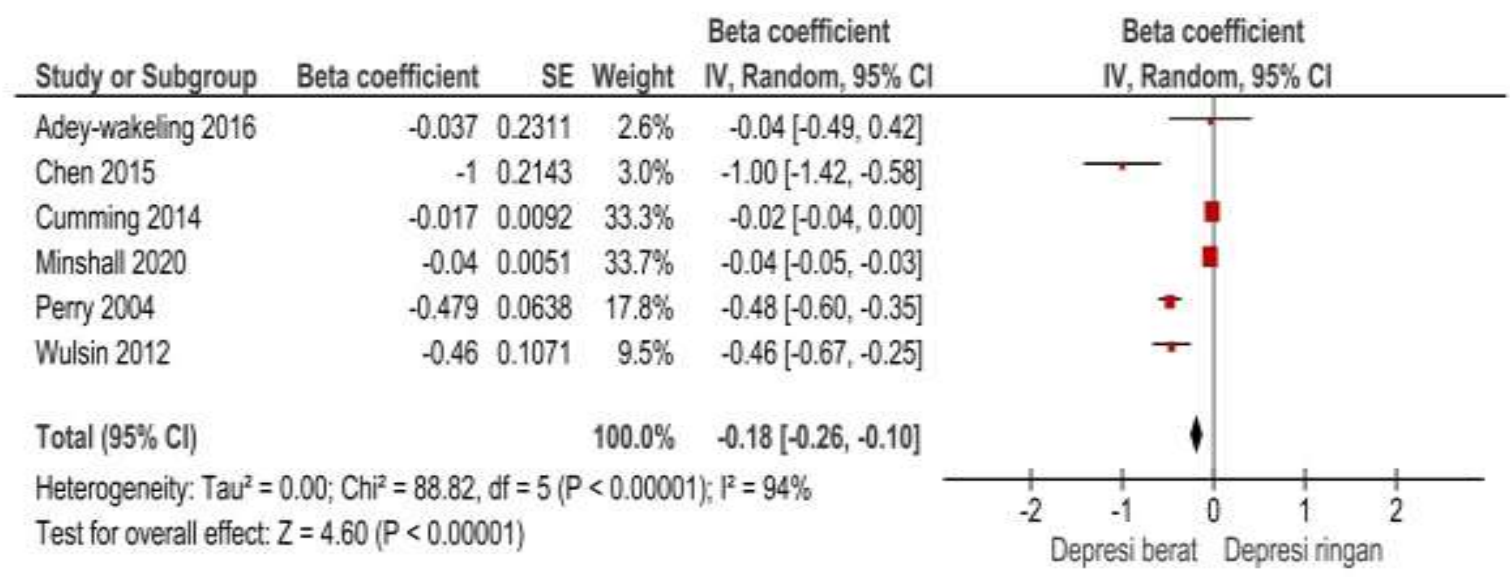

Figure 6. The forest plot of the effect of depression on the quality of life of stroke patients

\section{a. Funnel plot}

Figure 7 shows the funnel plot of the effect of depression on the quality of life of stroke patients. The funnel plot showed that the distribution of the study was symmetrical.
The distribution of plot points was balanced between the left and right sides of the centerline border. Therefore, there was no publication bias on the effect of depression on the quality of life of stroke patients.

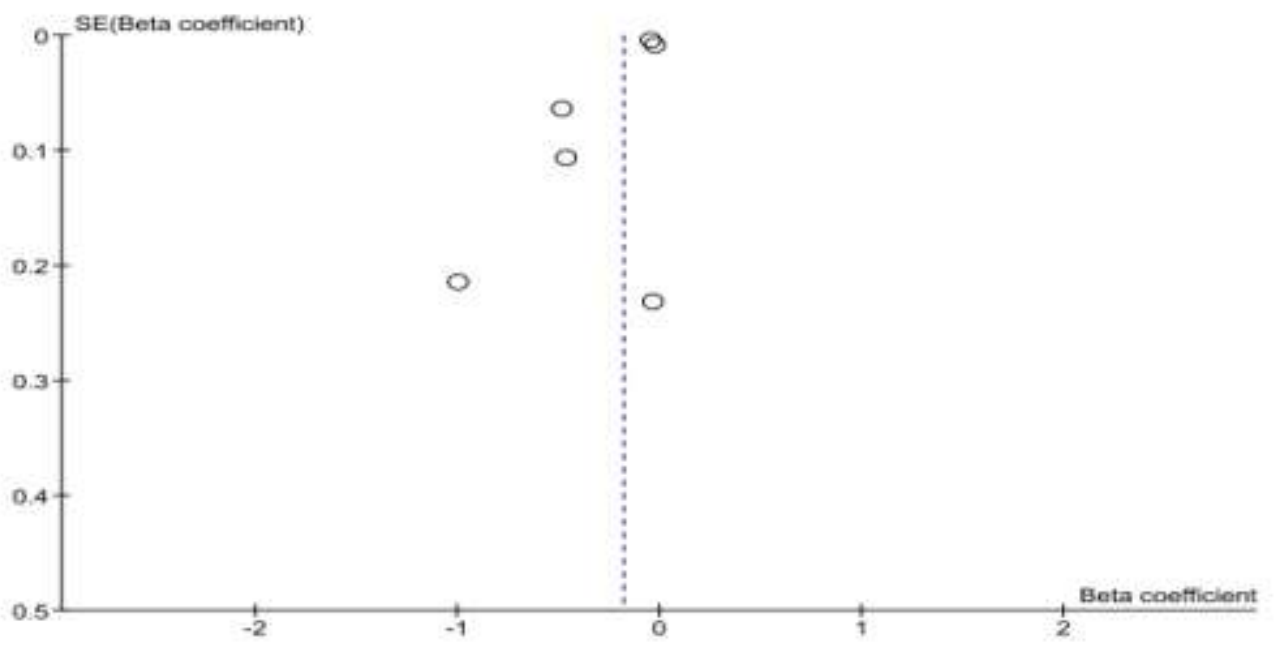

Figure 7. The funnel plot of the effect of depression on the quality of life of stroke patients 


\section{DISCUSSION}

The meta-analysis study included the result of the multivariate analysis only to control the confounding factor.

\section{The effect of social support on the quality of life of stroke patients}

The result of a meta-analysis of the effect of social support on the quality of life of stroke patients showed that strong social support improved the quality of life of stroke patients by 0.03 times compared to weak social support. A study conducted by Butsing et al., (2019) stated that social support in the form of emotional, information, and financial supports affected the quality of life of stroke patients. Besides, a study conducted by Alshahrani (2020) stated that social support from family and other people affected the quality of life of stroke patients.

\section{The effect of functional status on} the quality of life of stroke patients

The result of a meta-analysis of the effect of functional status on the quality of life of stroke patients stated that good functional status improved the quality of life of stroke patients by 0.63 times compared to poor functional status. A study conducted by Abubakar and Isezuo (2012) stated that the factor affecting the quality of life of stroke patients was functional status. Functional status was a factor that determined the quality of life of stroke patients (Gunaydin et al., 2011). A study conducted by Chaleoykitti et al., (2020) found that functional status affected the quality of life of stroke patients.

\section{The effect of depression on the quality of life of stroke patients}

The results of a meta-analysis of the effect of depression on the quality of life of stroke patients stated that major depression reduced the quality of life of stroke patients by 0.18 times compared to minor depression. A study conducted by Abubakar and Isezuo (2012) stated that depression was one of the factors affecting the quality of life of stroke patients. Symptoms of depression in acute stage were very important in predicting quality of life in 2 months after stroke. Depressed stroke patients would hinder all domains of quality of life (Zikic et al., 2014).

Stroke patients who had a reduced quality of life due to physical, social, and psychological disorders needed rehabilitation and appropriate interventions for poststroke recovery. Strong social support and good functional status could be used to improve the quality of life of stroke patients. Therefore, it is very important to identify patients at risk through depression screening because depression could reduce the quality of life of stroke patients.

There were several limitations to this study. 12 articles met the criteria where this study only focused on observational studies (cross-sectional and cohort studies). Besides, it was only multivariate analysis. Paid articles to get full-text articles were also a limitation in this study. In addition, this study used English language articles only due to the limitations of the author, thus creating language bias. As a result, there were only few data that could be used effectively in the analysis. Besides, the reliability of the study was reduced due to the high heterogeneity of the data.

\section{AUTHOR CONTRIBUTION}

Anwar Wahyudi was the main author who collected and processed the data. Didik Gunawan Tamtomo and RB Soemanto examined the conceptual framework and the study methodology.

\section{CONFLICT OF INTEREST}

We declare that there is no conflict of interest. 
Wahyudi et al./ Social Support, Functional Status, Depression, and Quality of Life

\section{FUNDING AND SPONSORSHIP}

This study did not use any funding and sponsorship due to the secondary data and the databases that could be easily accessed. It also provided open access journals.

\section{ACKNOWLEDGEMENT}

We thank to authors and online journal databases that provide research related with this study.

\section{REFERENCE}

Abubakar SA, Isezuo SA (2012). Health related quality of life of stroke survivors: experience of a stroke unit. Int $\mathrm{J}$ Biomed Sci. 8(11): 183-187. https://www.ncbi.nlm.nih.gov/pubmed/2367 5271.

Adey-Wakeling Z, Liu E, Crotty M, Leyden $\mathrm{J}$, Kleinig T, Anderson CS, Newbury J (2016). Hemiplegic shoulder pain reduces. Am J Phys Med Rehabil. 1-6. doi: 10.1097/PHM.0000000000000496.

Alshahrani AM (2020). Quality of life and social support: Perspectives of Saudi Arabian stroke survivors. Science Progress, 103(3): 1-16. doi: 10.1177/o036850420947603 .

Batool K, Ehsan S, Maqsood U, Arshad HS (2017). Effect of depression on stroke specific quality of life: A survey in urban settings of Lahore City. Electronic Journal of Biology. 13(4): 391394. Available at: https://ejbio.imedpub.com/abstract/effect-of-depression-on-stroke-specific-quality-of-lifearnsurvey-in-urban-settings-of-lahore-city-21464.html.

Browska-Bender M, Milewska M, Goła A, Duda-Zalewska A, Staniszewska A (2016). The impact of ischemic cerebral stroke on the quality of life of patients based on clinical, social, and psychoemotional factors. Journal of
Stroke and Cerebrovascular Diseases. 1-7. doi: 10.1016/j.jstrokecerebrovasdis.2016.08.036.

Butsing N, Tipayamongkholgul M, Ratanakorn N, Bunhamcharoen K (2019). Social support, functional outcome and quality of life among stroke survivors in an urban area. Journal of Pacific Rim Psychology, 13(May): 29. doi: 10.1017/prp.2019.2.

Canuto MÂO, Nogueira LT, Araújo TME. (2016). Health-related quality of life after stroke, ACTA Paulista de Enfermagem, 29(3): 245-252. doi: 10.1590/1982-0194201600035.

Chaleoykitti S, Srithumsuk W, Jaipong S (2020). Association between clinical characteristics and quality of life in older people with stroke at hospital discharge. 67-76. doi: 10.4236/aar.2020.94006.

Chen CM, Tsai CC, Chung CY, Chen CL, Wu $\mathrm{KPH}$, Chen HC (2015). Poststroke fatigue: risk factors and its effect on functional status and health-related quality of life. World Stroke Organization. 10: 506-512. doi: 10.1111/ijs.12409.

Choi-Kwon S, Choi SH, Suh M, Choi S, Cho KH, Nah HW, Song H, Kim JS (2016). Musculoskeletal and central pain at 1 year post-stroke: associated factors and impact on quality of life, Acta Neurologica Scandinavica, 135(4): 419-425. doi: 10.1111/ane.12617.

Cumming TB, Brodtmann A, Darby D, Bernhardt J (2014). The importance of cognition to quality of life after stroke. Journal of Psychosomatic Research. 77(5): 374-379. doi: 10.1016/j.jpsychores.2014.08.009.

Elmawla DAEA, ABdelraf AI, Elsaid RAEAE (2019). Determinants of healthrelated quality of life among middleaged and older stroke patients. World 
Wahyudi et al./ Social Support, Functional Status, Depression, and Quality of Life

Journal of Nursing Sciences. 5(3): 136-147. doi: 10.5829/idosi.wjns.2019.136.147.

Fan Y, Liang X, Han L, Shen Y, Shen B, Chen C, Sun Y, Wang J, Tang Y (2020). Determinants of quality of life according to cognitive status in parkinson's disease. Frontiers in Aging Neuroscience. 12(August): 1-8. doi: 10.3389/fnagi.2020.00269.

Gunaydin R, Karatepe AG, Kaya T, Ulutas O. (2011). Determinants of quality of life (QoL) in elderly stroke patients: A short-term follow-up study. 53: 1923. doi: 10.1016/j.archger.2010.06.004.

Gurcay E, Bal A, Cakci A. (2009). Healthrelated quality of life in first-ever stroke patients. Annals of Saudi Medicine. King Faisal Specialist Hospital and Research Centre. 29(1): 36-40. doi: 10.4103/0256-4947.51814.

Hammed AI, Ugboh E (2018). Association between self-esteem, depression, social support, and quality of life among patients with cerebrovascular accidents and spinal cord injury, clinical medicine journal. 4(3): 3843. doi: 10.15282/mohe.v7i1.155.

Karlinda, Tamtomo DG, Murti B (2019). Obesity and diabetes mellitus as predictors of mortality in patients with stroke: A meta analysis. Indones $\mathrm{J}$ Med. 4(4): 383-393. doi: https://doi.org/10.26911/theijmed.2019.04.0 4.12.

Khalid W, Rozi, S, Ali TS, Azam I, Mullen MT, Illyas S, Nisa Q, Soomro N, Kamal AK (2016). Quality of life after stroke in Pakistan. BMC Neurol. 1-12. doi: 10.1186/s12883-016-0774-1.

Krishnamurthi RV, Ikeda T, Feigin VL (2020). Global, regional and countryspecific burden of ischaemic stroke, intracerebral haemorrhage and sub- arachnoid haemorrhage: A systematic analysis of the global burden of disease study 2017, Neuroepidemiology. doi: 10.1159/000506396.

Lima RJ, Pimenta CJL, Frazao MCLO, Ferreira GRS, Costa TF, Viana LRC, Martins KP, Costa KNFM (2019). Functional capacity and social support to people affected by cerebrovascular accident. Revista brasileira de enfermagem. 72(4): 868-873. doi: 10.159o/0034-7167-2017-0854.

Minshall C, Ski CF, Apputhurai P, Thompson DR, Castle DJ Jenkins Z, Knowles SR. (2020). Exploring the impact of illness perceptions, self-efficacy, coping strategies, and psychological distress on quality of life in a poststroke cohort. J Clin Psychol Med Settings. (0123456789). doi: 10.1007/s10880-020-09700-0.

Pandit RB. (2020). Health related quality of life of cerebrovascular accident patient: A descriptive study. 10(January): 1-4. Retrieved from www.ijhsr.org

Patel AR, Patel AR, Desai S (2019). The underlying stroke etiology: A comparison of two classifications in a rural setup. Cureus, 179(7). doi: 10.7759/cureus.5157.

Pedersen SG, Anke A, Aadal L, Pallesen H, Moe S, Arntsen C (2019). Experiences of quality of life the first year after stroke in Denmark and Norway. A qualitative analysis. International Journal of Qualitative Studies on Health and Well-being. 14(1). doi: 10.1080/17482631.2019.1659540.

Pei L, Zang XY, Wang Y, Chai QW, Wang JY, Sun CY, Zhang Q. (2016). Factors associated with activities of daily living among the disabled elders with stroke, International Journal of Nursing Sciences. 3(1): 29-34. doi: 10.1016/j.ijnss.2016.01.002. 
Wahyudi et al./ Social Support, Functional Status, Depression, and Quality of Life

Perry L, McLaren S (2004a). An exploration of nutrition and eating disabilities in relation to quality of life at 6 months post-stroke, Health and Social Care in the Community. 12(4): 288297. doi: 10.1111/j.1365-2524.2004.00494.x.

Perry L, McLaren S (2004b). An exploration of nutrition and eating disabilities in relation to quality of life at 6 months post-stroke, Health and Social Care in the Community. 12(4): 288-297. doi: 10.1111/j.1365-2524.2004.00494.x.

Pratiwi DI, Tamtomo D, Murti B (2019). Is cognitive impairment a risk factor for post-stroke depression? A meta-analysis study. J Epidemiol Public Health. 4(2): 81-87. doi: https://doi.org/10.26911/jepublichealth.2019.04. 02.03 .

Setiawan ID, Trisyani Y, Lumbantobing VBM (2018). Pengalaman hidup pasien paska stroke di Bandung (The life experiences of post-stroke patients in Bandung). Journal Nursing Care and Biomolecular. 3(1): 42. doi: 10.32700/jnc.v3i1.70.
Terrill AL, Schwartz JK, Belagaje SR (2018). Best practices for the interdisciplinary rehabilitation team: A review of mental health issues in mild stroke survivors. Stroke Research and Treatment. doi: 10.1155/2018/6187328.

Wulsin L, Alwell K, Moomaw CJ, Lindsell CJ, Kleindorfer DO, Woo D, Flaherty ML, et al. (2012). Comparison of two depression measures for predicting stroke outcomes. Journal of Psychosomatic Research. 72(3): 175-179. doi: 10.1016/j.jpsychores.2011.11.015.

Zhu W, Jiang Y (2019). Determinants of quality of life in patients with hemorrhagic stroke: A path analysis. Medicine. 98(5): e13928. doi: 10.1097/MD.0000000000013928.

Zikic TR, Divjak I, Jovicevic M, Semnic M, Slankamenac PP, Zarkov M, Zikic M (2014). The effect of post stroke depression on functional outcome and quality of life. Acta Clin Croat. 53(3): 294-301. PMID: 25509239. 